NOTE

\title{
Intertidal oyster reefs can persist and function in a temperate North American Atlantic estuary
}

\author{
Jaclyn Taylor*, David Bushek \\ Haskin Shellfish Research Laboratory, Rutgers University, Port Norris, New Jersey 08349, USA
}

\begin{abstract}
Intertidal oyster reefs in lower Delaware Bay are ephemeral and it is generally assumed that oyster mortality due to predation, disease and winter ice scouring inhibits their persistence. In June 2006, shell-bag oyster reefs of varying height were constructed on the intertidal sand flats in lower Delaware Bay, USA, to determine the potential for oyster reef restoration in this temperate estuary. Oyster settlement, mortality and recruitment were compared among reefs, as was habitat value for motile fauna. Oysters recruited shortly after reefs were constructed. Motile macrofauna immediately began using the reefs, increasing species richness and abundance relative to the adjacent sand flat. Little post-settlement mortality was observed in oysters by October 2006 and most survived exposure to snow and ice during winter. Shifting sediments nearly buried the shortest reef by April 2007, a process that may be more important in limiting the development of oyster reefs in this system than predation, disease or ice shear. Results indicate that there is good potential for the development of intertidal oyster reefs in this region.
\end{abstract}

KEY WORDS: Crassostrea virginica $\cdot$ Habitat $\cdot$ Recruitment $\cdot$ Mortality $\cdot$ Sedimentation $\cdot$ Delaware Bay

Resale or republication not permitted without written consent of the publisher

\section{INTRODUCTION}

As in many North American Atlantic Coast estuaries, the Eastern oyster Crassostrea virginica Gmelin is strongly linked to the history and socio-economic structure of communities surrounding Delaware Bay, USA. Post-World War II technological improvements facilitated a rapid expansion of the oyster fishery until overfishing and 2 virulent oyster diseases (Dermo and MSX) decimated the industry (Farley 1988, Ford 1996). A sustainable subtidal population remains and supports a small but viable fishery (Canzonier et al. 1998); however, recent recruitment failures nearly forced its closure (Powell et al. 2006, 2007). As a result, a major subtidal shell-planting program is in progress to increase oyster recruitment and production for the fishery (US ACE 2006).

In addition to the socio-economic structure it supports, Crassostrea virginica is also ecologically valu- able. Dame (1996) summarizes a variety of ecosystem processes influenced by marine bivalve molluscs, one of which is creation of habitat. Gregariously settling oysters form beds and reefs that create spatial heterogeneity, giving the beds an intrinsic habitat value (Breitburg 1992, Harding \& Mann 2000). This habitat provides nursery grounds and refuge from predation, as well as reproduction and foraging sites for a variety of estuarine species (Coen \& Luckenbach 2000, Harding \& Mann 2001, Luckenbach et al. 2005, Rodney \& Paynter 2006). Studies in Virginia, Maryland, Louisiana and the Carolinas have quantified (1) increases in species diversity and abundance (Coen et al. 1999, Coen \& Luckenbach 2000, Breitburg et al. 2000, Luckenbach et al. 2005), (2) effects of intertidal reefs on reducing shoreline erosion (Meyer et al. 1997, Piazza et al. 2005) and (3) effects of reef height on recruitment and persistence (Lenihan 1999, Nestlerode et al. 2007), via the creation and restoration of 
oyster beds and reefs. In Delaware Bay, Maurer \& Watling (1973) surveyed the fauna associated with subtidal oyster beds. Intertidal oyster reefs occasionally form along the Cape Shore in lower Delaware Bay (Fig. 1), but few studies have examined their ecology. The Cape Shore consistently receives high oyster recruitment (Powell et al. 2007), but substrate is limiting and mortality is high, resulting in the formation of ephemeral oyster reef habitat. This study investigated the use of shell-bags to construct intertidal oyster reefs. Our objective was to gather information about the effects of reef height on (1) oyster recruitment and mortality, (2) habitat utilization by motile fauna and (3) reef persistence within the intertidal zone.

\section{MATERIALS AND METHODS}

In June 2006, 3 oyster shell-bag reefs were constructed on the sand flats of the Cape Shore region of lower Delaware Bay, USA (Fig. 1A). Mesh bags (14.3 mm opening) were filled with $19 \mathrm{l}$ of oyster shell and arranged side-by-side in a $1.5 \mathrm{~m} \times 3 \mathrm{~m}$ rectangular footprint to form the base of each reef. The shell-bag reefs mimic the small oyster reefs that form periodically on the sand flats (Fig. 1B-E). Reefs were separated by $10 \mathrm{~m}$, aligned parallel to the beach and contained 1 (Reef 1), 2 (Reef 2) and 3 (Reef 3) layers of shell-bags; each layer was ca. $16 \mathrm{~cm}$ high. Maximum tidal amplitude at the Cape Shore is $\sim 2.75 \mathrm{~m}$. During
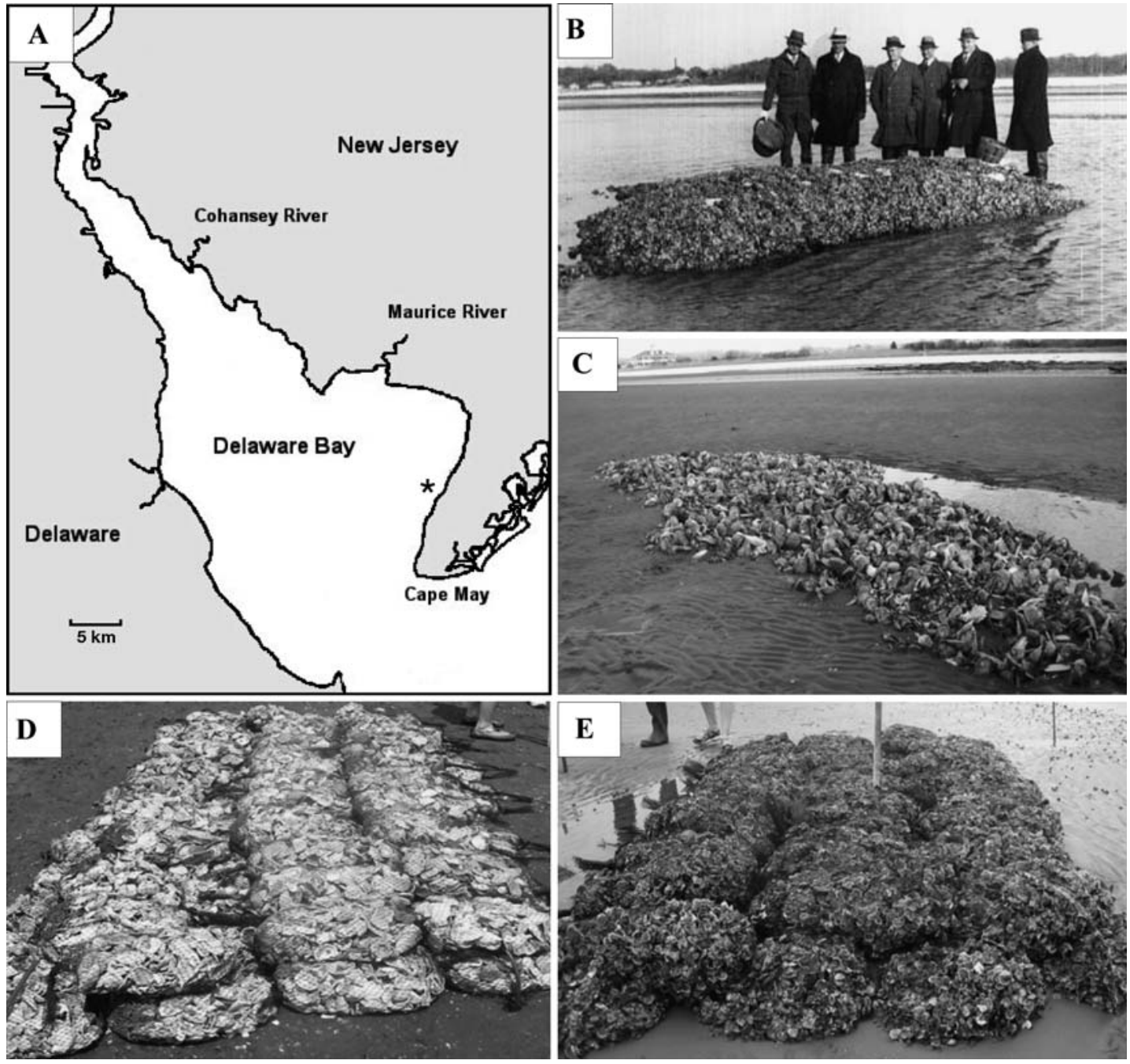

Fig. 1. (A) Lower Delaware Bay showing location of study site ( $\star^{\prime}$ : $39^{\circ} 04^{\prime} 25^{\prime} \mathrm{N}, 74^{\circ} 54^{\prime} 46^{\prime} \mathrm{W}$ ) at Rutgers' Cape Shore Hatchery Facility near Green Creek, New Jersey. (B) Historical (ca. 1940) intertidal oyster reef at study site. (C) Recent (ca. 2004) intertidal oyster reef at study site. (D) Two-layer shell-bag reef constructed on intertidal sand flats, 26 June 2006, before recruitment.

(E) Two-layer shell-bag reef on 5 October 2006, after natural oyster recruitment 

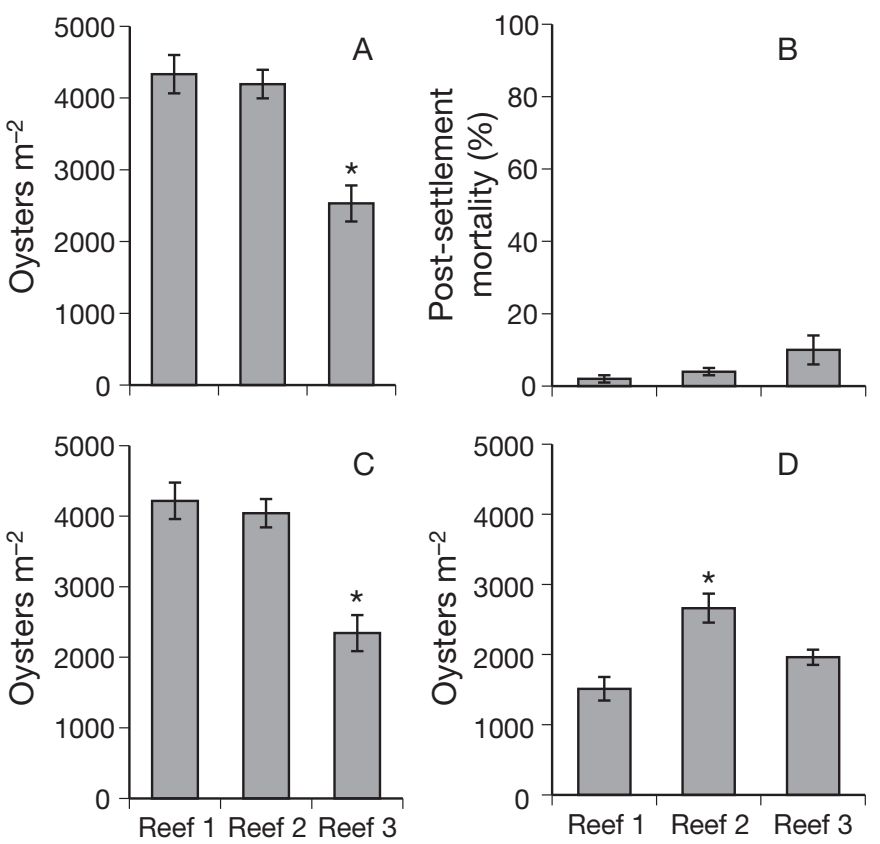

Fig. 2. Crassostrea virginica. (A) Estimated settlement, (B) post-settlement mortality through October 2006, (C) recruitment through October 2006 and (D) abundance in April 2007. Data are means \pm SE calculated from $10 \mathrm{~cm}^{2}$ quadrats (n $=16$ per reef). ${ }^{*} \mathrm{p}<0.001$ for Tukey's post hoc comparisons

high tide, the mean water depth was $\sim 2$ m where the constructed reefs were located. Reefs were exposed for $\sim 4$ h during low tide.

On 5 October 2006 and 10 April 2007, live and dead oysters were counted on all 3 shell-bag reefs without disturbing reef structure by using a $10 \mathrm{~cm}^{2}$ quadrat haphazardly placed along 4 transects ( $\mathrm{n}=16$ per reef). Transects were perpendicular to the beach and approximately evenly spaced across each reef. Settlement was estimated as the sum of live and dead oysters $\mathrm{m}^{-2}$ in October 2006. Dead oysters included boxes (empty valves), gapers (boxes containing oyster tissue) and scars (marks left from recently detached oysters). Post-settlement mortality was estimated as the number of dead oysters divided by the number of dead plus live oysters in October 2006. Recruitment was defined as the number of live oysters $\mathrm{m}^{-2}$ in October 2006. Overwinter survival was calculated as the number of live oysters $\mathrm{m}^{-2}$ in April 2007 divided by October oyster recruitment. One-way ANOVA and Tukey's post hoc comparisons ( $\alpha=0.05$ ) were used to test for differences among reefs in oyster settlement, recruitment, postsettlement mortality, and April 2007 oyster abundance. Reef persistence over time was documented photographically.

Motile fauna were sampled every 2 wk with unbaited, galvanized steel $6.35 \mathrm{~mm}$ mesh traps (length =
$45 \mathrm{~cm}$, diameter $=23 \mathrm{~cm}, 25.4 \mathrm{~mm}$ funnel entrances at each end) secured to the reef base or in a control sand area (10 $\mathrm{m}$ from the nearest reef) during low tide. At the next low tide, all individuals captured were identified to species and enumerated. Sixteen collections were conducted from 27 July to 16 October 2006 using 1 trap per treatment, while 4 collections were completed from 17 to 26 October 2006 using 5 traps per treatment.

\section{RESULTS}

Natural oyster settlement occurred shortly after reefs were constructed and extensive recruitment was evident in October (Fig. 1E). Estimated settlement and recruitment through October 2006 for Reefs 1 and 2 were significantly greater and nearly double that of Reef 3 (Fig. 2A,C). Post-settlement mortality through October 2006 increased from Reef 1 to Reef 3, reinforcing the pattern of differential settlement. At this time, mortality was $10 \%$ or less for all reefs and differences among reefs were not statistically significant (Fig. 2B, $\mathrm{p}=0.08)$. In contrast, over-winter mortality was greatest on Reef 1 (64\% vs. 34 and $16 \%$ on Reefs 2 and 3, respectively); this altered live oyster abundances among reefs by April 2007 (Fig. 2D). Highest oyster abundance in April 2007 occurred on Reef 2 and was significantly greater than abundances on Reef 1 and Reef 3.

The primary cause of over-winter mortality on Reef 1 was sedimentation (Fig. 3). Shortly after reef construction, sediments accumulated in front of each reef. Small, shallow ( $<10 \mathrm{~cm}$ deep) tidal pools often formed behind each reef, increasing in area with the height of the reef. By April 2007, sediments covered most of Reef 1, eliminating any remnants of a tidal pool. The heights of Reef 2 and Reef 3 protected them from the effects of sedimentation. Sediments accumulated in the first layer of each reef, but the accumulation decreased with reef height (Fig. 3).

Thirteen different motile species were collected on the reefs while only 7 species were captured on the sand flat (Table 1). All species collected on the sand flat were present on the reefs and faunal abundances were higher on reefs than on the sand flat. Total abundance was inversely related to reef height (Table 1). The most commonly observed reef species were Palaemonetes pugio, Nassarius obsoletus and Pagarus longicarpus. P. pugio was the dominant species on all 4 sampling sites, while $N$. obsoletus was collected exclusively on the reefs. The yellow-phase American eel Anguilla rostrata was the most abundant of 5 fish species and was associated solely with the reefs. 

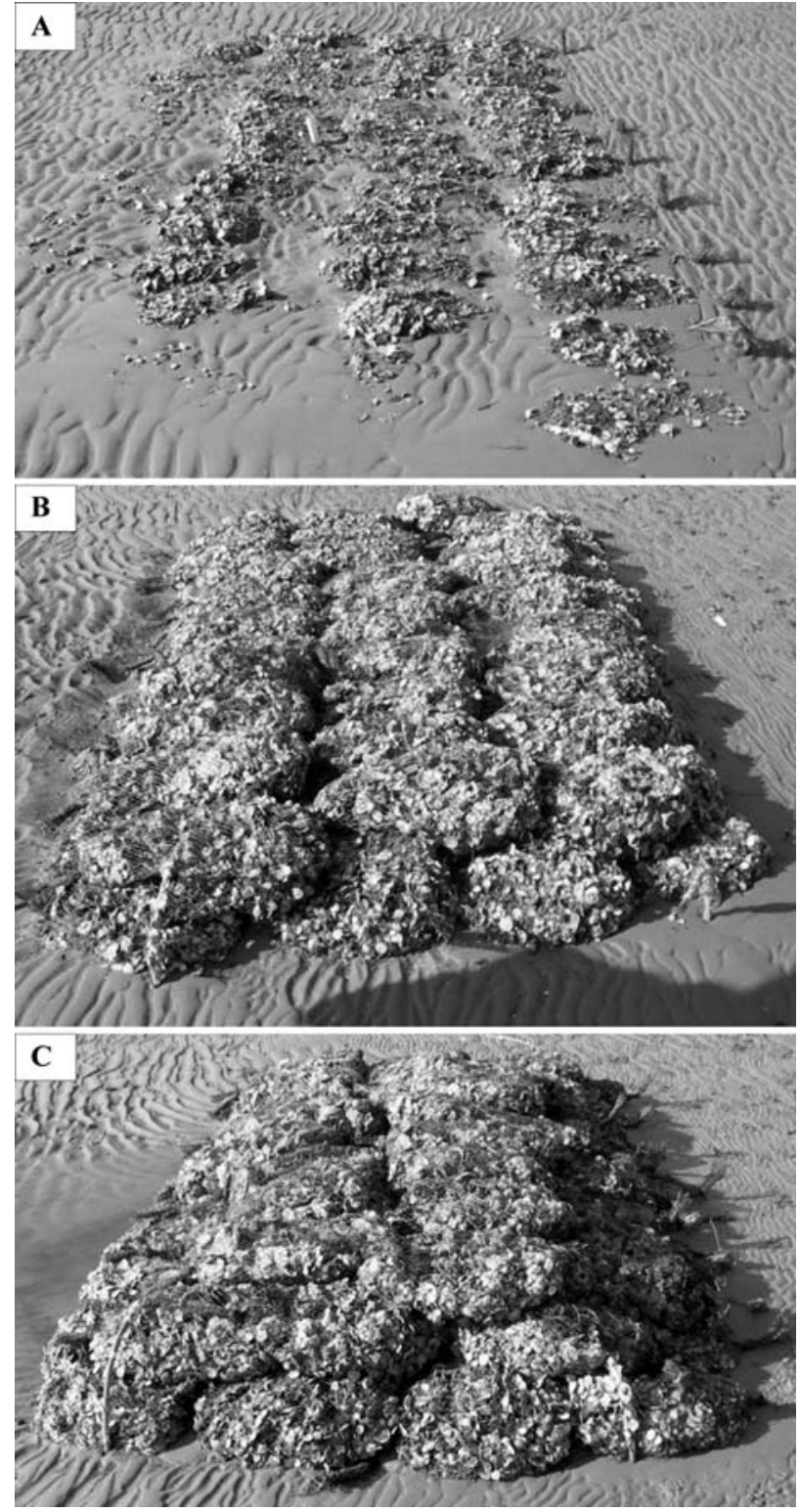

Fig. 3. Photographs comparing sedimentation around (A) Reef 1, (B) Reef 2 and (C) Reef 3 in April 2007

\section{DISCUSSION}

This study demonstrates the utility of shell-bag reefs for creating oyster reef habitat in temperate estuaries. The reefs consisted of wild oysters set on disarticulated shell, creating a habitat matrix similar to a natural oyster bed, which was quickly utilized by typical oyster reef fauna (Maurer \& Watling 1973, Luckenbach et al. 2005). Oyster settlement, recruitment, survival and reef persistence varied according to reef height.

Although lower Delaware Bay is the highest oyster settlement zone in the bay (Powell et al. 2006, 2007), persistent intertidal reefs do not form. The absence of intertidal reefs in this region of the bay is often attributed to predation, disease, and freezing or ice shear. Our data demonstrate that shifting sediments contribute to the ephemeral nature of intertidal reefs. During winter 2007, several feet of ice accumulated on the Cape Shore flats (G. DeBrosse, Rutgers Cape Shore Shellfish Hatchery Manager, pers. comm.), yet oysters survived and Reefs 2 and 3 persisted. Therefore, it seems more likely that shifting sediments inhibit the formation of intertidal reefs rather than predation or harsh winter conditions. Both MSX and Dermo disease are highly prevalent at the Cape Shore (Haskin \& Andrews 1988, Ford 1996), but generally cause mortality in older oysters and were not expected to significantly affect the oysters observed in this study.

Results indicated that oyster habitat supports a greater abundance and perhaps a greater species richness of motile species than the adjacent sand flats. Decapod crustacean abundance on reefs was twice that on the sand flat, and 5 fish species utilized the reefs while only 3 species were captured on the sand flats. The highest species richness and abundance observed corresponded with the reef that supported greatest oyster recruitment (Reef 1), although this reef did not persist. Interestingly, 5 American eels Anguilla rostrata of increasingly larger size were captured over the course of the summer and fall on reefs, but not on the adjacent sand flat. The timing of these captures corresponds to eel migrations and may indicate that the oyster reef structure provides a useful refuge or foraging habitat for eels during their migrations.

Other studies have found similar responses. For example, in Chesapeake Bay, Rodney \& Paynter (2006) observed a 4 -fold increase in xanthid crabs and demersal fish on restored subtidal oyster reefs over nonrestored controls and Palaemonetes pugio abundance was more than 10 times greater on restored reefs. On the Eastern Shore of Virginia, Arve (1960) found that 3 times as many fish were captured over subtidal shell plantings as on unplanted controls. Results from the present study show a 4 -fold increase in xanthid crabs and almost twice the number of fish species on intertidal reefs as on sand flat. In South Carolina, Luckenbach et al. (2005) found that the decapod crabs Eurypanopeus depressus and Panopeus herbstii, which naturally inhabit intertidal reefs, were good indicators of community development on restored intertidal oyster reefs. Both crab species were captured in the present study, albeit at low frequencies with the gear used. These species are common on subtidal oyster beds elsewhere in Delaware Bay and, with a more appropriate sampling method, may likewise be good indicator species for intertidal oyster reefs in Delaware Bay. Sampling gear is known to influence size and 
Table 1. Species sampled with wire mesh traps on the 3 intertidal shell-bag reefs and control sand plot. Values denote total number of individuals collected. Total abundance and species richness is shown for all 4 sampling sites. Reef 1: 1 shell-bag layer; Reef 2: 2 shell-bag layers; Reef 3: 3 shell-bag layers. Fish species and common names referenced from Nelson et al. (2004). Invertebrate species and common names referenced from Williams et al. (1989) and Turgeon et al. (1998)

\begin{tabular}{|c|c|c|c|c|c|}
\hline Species name & Common name & Sand & Reef 1 & Reef 2 & Reef 3 \\
\hline \multicolumn{6}{|l|}{ Teleosts } \\
\hline Anguilla rostrata & American eel & 0 & 1 & 2 & 2 \\
\hline Bairdiella chrysoura & Silver perch & 1 & 1 & 1 & 0 \\
\hline Lagodon rhomboides & Pinfish & 1 & 1 & 0 & 1 \\
\hline Menidia menidia & Atlantic silverside & 2 & 0 & 0 & 1 \\
\hline Opsanus tau & Oyster toadfish & 0 & 0 & 1 & 0 \\
\hline \multicolumn{6}{|l|}{ Crustaceans } \\
\hline Palaemonetes pugio & Daggerblade grass shrimp & 15 & 40 & 35 & 29 \\
\hline Pagurus longicarpus & Longwrist hermit crab & 10 & 19 & 11 & 20 \\
\hline Callinectes sapidus & Blue crab & 4 & 2 & 5 & 2 \\
\hline Panopeus herbstii & Atlantic mud crab & 1 & 3 & 0 & 0 \\
\hline Crangon septemspinosa & Seven spine sand shrimp & 0 & 2 & 1 & 0 \\
\hline Eurypanopeus depressus & Flatback mud crab & 0 & 1 & 0 & 1 \\
\hline Rhithropanopeus harrisii & Harris mud crab & 0 & 1 & 0 & 0 \\
\hline \multicolumn{6}{|l|}{ Gastropods } \\
\hline Nassarius obsoletus & Eastern mud snail & 0 & 15 & 11 & 6 \\
\hline Total abundance & & 34 & 86 & 67 & 62 \\
\hline Species richness & & 7 & 11 & 8 & 8 \\
\hline
\end{tabular}

composition of fauna collected. For example, Able et al. (2005) found that fish $<20 \mathrm{~mm}$ total length were never captured in wire mesh traps. In the present study, small naked gobies Gobiosoma bosc were often observed in the reefs, but were never trapped. A more comprehensive sampling regime will likely reveal additional insights into the habitat value of intertidal oyster reefs in temperate estuaries like Delaware Bay.

Intertidal oyster reefs have been shown to reduce shoreline erosion along the southeastern Atlantic coast of the United States (Meyer et al. 1997) and in the northern Gulf of Mexico (Piazza et al. 2005). Rates of erosion are high in many areas of Delaware Bay, including the Cape Shore (Phillips 1986). In addition to property loss, erosion has eliminated valuable beach, dune, and marsh habitats, negatively affecting fisheries production, horseshoe crab spawning, and migratory shore bird foraging. The survival of the 2 taller intertidal reefs indicates that constructed intertidal oyster reefs represent a potentially viable strategy for reducing erosion in Delaware Bay and similar temperate estuaries, while also providing additional ecological services through the creation of a novel habitat and the ecological functions associated with oyster reefs.

Acknowledgements. We thank F. Fuentes and E. Scarpa for field assistance. K. Able and J. Grassle provided insightful comments and discussion. Partial support was provided by the Rutgers University Research Council Program, the New Jersey Water Resources Research Institute and Dupont's Clear into the Future Delaware Estuary Initiative.

\section{LITERATURE CITED}

Able KW, Smith KJ, Hagan SM (2005) Fish composition and abundance in New Jersey salt marsh pools: sampling technique effects. Northeast Nat 12:485-502

Arve J (1960) Preliminary report on attracting fish by oystershell planting in Chincoteague Bay, Maryland. Chesapeake Sci 1:58-65

Breitburg DL (1992) Episodic hypoxia in Chesapeake Bay: interacting effects of recruitment, behavior, and physical disturbance. Ecol Monogr 62:525-546

Breitburg DL, Coen LD, Luckenbach MW, Mann R, Posey M, Wesson JA (2000) Oyster reef restoration: convergence of harvest and conservation strategies. J Shellfish Res 19: 371-377

Canzonier WJ, Ford SE, Gandy J, Kraeuter JN (1998) Varying the timing of oyster seed transplants to maximize yield. J Shellfish Res 17:349-350

Coen LD, Luckenbach MW (2000) Developing success criteria and goals for evaluating oyster reef restoration: ecological function or resource exploitation? Ecol Eng 15:323-343

Coen LD, Luckenbach MW, Breitburg DL (1999) The role of oyster reefs as essential fish habitat: a review of current knowledge and some new perspectives. In: Benaka LR (ed) Fish habitat: essential fish habitat and rehabilitation. American Fisheries Society Symposium 22, Bethesda, MD, p 438-454

Dame RF (1996) Ecology of marine bivalves: an ecosystem approach. CRC Press, Boca Raton, FL

Farley CA (1988) Mass mortalities and infectious lethal diseases in bivalve mollusks and associations with geographic transfers of populations. J Shellfish Res 7:554

Ford SE (1996) Range extension by the oyster parasite Perkinsus marinus into the northeastern United States: response to climate change? J Shellfish Res 15:45-56

Harding JM, Mann R (2000) Estimates of naked goby (Gobiosoma bosc), striped blenny (Chasmodes bosquianus) and 
eastern oyster (Crassostrea virginica) larval production around a restored Chesapeake Bay oyster reef. Bull Mar Sci 66:29-45

Harding JM, Mann R (2001) Oyster reefs as fish habitat: opportunistic use of restored reefs by transient fishes. J Shellfish Res 20:951-959

Haskin HH, Andrews JD (1988) Uncertainties and speculations about the life cycle of the Eastern oyster pathogen Haplosporidium nelsoni (MSX). In: Fisher WS (ed) Disease processes in marine bivalve molluscs. American Fisheries Society Spec Publ 18, Bethesda, MD

Lenihan HS (1999) Physical-biological coupling on oyster reefs: how habitat structure influences individual performance. Ecol Monogr 69:251-275

Luckenbach MW, Coen LD, Ross PG, Stephen JA (2005) Oyster reef habitat restoration: relationships between oyster abundance and community development based on two studies in Virginia and South Carolina. J Coast Res 40: $64-78$

Maurer D, Watling L (1973) The biology of the oyster community and its associated fauna in Delaware Bay. Delaware Bay Report Series Vol 6, College of Marine Studies University of Delaware, Newark, DE

Meyer DL, Townsend EC, Thayer GW (1997) Stabilization and erosion control value of oyster cultch for intertidal marsh. Restor Ecol 5:93-99

Nelson JS, Crossman EJ, Espinosa-Perez H, Findley LT, Gilbert CR, Lea RN, Williams JD (2004) Common and scientific names of fishes from the United States, Canada and Mexico, 6th edn. American Fisheries Society Spec Publ 29, Bethesda, MD

Nestlerode JA, Luckenbach MW, O'Beirn FX (2007) Settlement and survival of the oyster Crassostrea virginica on

Editorial responsibility: Kenneth Heck,

Dauphin Island, Alabama, USA created reef habitats in Chesapeake Bay. Restor Ecol 15: 273-283

Phillips JD (1986) Spatial analysis of shoreline erosion, Delaware Bay, New Jersey. Ann Assoc Am Geogr 76:50-62

> Piazza BP, Banks PD, La Peyre MK (2005) The potential for created oyster shell reefs as a sustainable shoreline protection strategy in Louisiana. Restor Ecol 13:499-506

Powell E, Kraeuter J, Ashton-Alcox K (2006) Report of the 2006 Stock Assessment Workshop for the New Jersey Delaware Bay oyster beds. Haskin Shellfish Research Laboratory Report, Port Norris, NJ

Powell E, Kraeuter J, Ashton-Alcox K (2007) Report of the 2007 Stock Assessment Workshop for the New Jersey Delaware Bay oyster beds. Haskin Shellfish Research Laboratory Report, Port Norris, NJ

Rodney WS, Paynter KT (2006) Comparisons of macrofaunal assemblages on restored and non-restored oyster reefs in mesohaline regions of Chesapeake Bay in Maryland. J Exp Mar Biol Ecol 335:39-51

Turgeon DD, Quinn JF Jr, Bogan AE, Coan EV and others (1998) Common and scientific names of aquatic invertebrates from the United States and Canada: mollusks, 2nd edn. American Fisheries Society Spec Publ 26, Bethesda, $\mathrm{MD}$

US ACE (2006) Delaware Bay oyster restoration project: Delaware and New Jersey Final Environmental Assessment. US Army Corps of Engineers Philadelphia District Report, US ACE, Philadelphia, PA

Williams AB, Abele IG, Felder DL, Hobbs HH Jr, Manning RB, McLaughlin PA, Perez Farfante I (1989) Common and scientific names of aquatic invertebrates from the United States and Canada: decapod crustaceans. American Fisheries Society Spec Publ 17, Bethesda, MD

Submitted: August 27, 2007; Accepted: January 25, 2008 Proofs received from author(s): May 27, 2008 